\title{
PENGARUH KEADILAN PROSES SELEKSI DAN NEGOSIASI GAJI TERHADAP DAYA TARIK ORGANISASI DENGAN REPUTASI PERUSAHAAN SEBAGAI VARIABEL MEDIASI
}

\author{
Octavianus Sumardana Pratama ${ }^{1}$ \\ Agoes Ganesha Rahyuda ${ }^{2}$ \\ ${ }^{1,2}$ Fakultas Ekonomi dan Bisnis Universitas Udayana (Unud), Bali, Indonesia \\ Email: sumardanapratama@gmail.com
}

\begin{abstract}
ABSTRAK
Penting mengelola daya tarik organisasi, sehingga dapat menarik minat calon pelamar pekerjaan yang memiliki kompetensi unggul dan sesuai dengan kebutuhan organisasi. Perusahaan menyadari bahwa dalam mendapatkan calon karyawan potensial adalah dengan membuat prosedur seleksi yang adil bagi calon karyawan. Negosiasi gaji menjadi aspek yang tidak dapat dipisahkan dalam keberhasilan proses perekrutan calon karyawan. Faktor-faktor seperti keadilan proses seleksi dan negosiasi gaji yang telah dilakukan perusahaan akan dapat meningkatkan reputasi perusahaan dan tentunya akan menarik minat untuk melamar pekerjaan di organisasi tersebut. Sampel yang digunakan adalah guru tetap dan guru tidak tetap pada sekolah TK,SD,SMP dan SMA Santo Yoseph Denpasar yang berjumlah 53 responden dengan teknik pengumpulan sampel menggunakan teknik sampling proporsional. Penelitian ini menggunakan teknik analisis PLS (Partial Least Square). Hasil penelitian menemukan bahwa keadilan proses seleksi dan negosiasi gaji memiliki pengaruh positif dan signifikan terhadap reputasi perusahaan. Selanjutnya, keadilan proses seleksi dan negosiasi gaji memiliki pengaruh positif dan signifikan terhadap daya tarik organisasi. Terakhir, reputasi perusahaan sebagai variabel pemediasi berpengaruh positif dan signifikan terhadap hubungan keadilan proses seleksi dan negosiasi gaji terhadap daya tarik organisasi.
\end{abstract}

Kata Kunci: Keadilan proses seleksi, negosiasi gaji, reputasi perusahaan dan daya tarik organisasi

\begin{abstract}
The importance of organizational attractiveness management, attract potential job applicants who have superior competence and it suitables with the needs of the organization. The company realized that the way in getting potential employee candidates was made a fair selection procedure for prospective employees. Salary negotiation becomes an inseparable aspect in the recruitment process. The factors as well as the selection fairness and the salary negotiations that the company has made will improve the firm reputation and it certainly attract interest in applying for jobs. The sample were 53 respondents from permanent and non-permanent teachers at kindergarten, elementary, junior, and senior high school of Santo Yoseph Denpasar by using proportional sampling technique. This research used analysis technique PLS (Partial Least Square). The results showed that the selection fairness and the salary negotiation had a positive and significant impact on the firm reputation. Furthermore, they had a positive and significant influence on the organizational attractiveness. Besides that, the firm reputation as a mediating variable had a positive and significant impacts to the selection fairness and the salary negotiation on the organizational attractiveness.
\end{abstract}

Keywords: Selection fairness, salary negotiation, firm reputation, and organizational attractiveness. 


\section{PENDAHULUAN}

Daya tarik organisasi (organizational attractiveness) merupakan fondasi penting bagi perusahaan untuk mencapai keunggulan kompetitif (Turban et al., 2001). Jika dilihat dari perspektif pengelolaan SDM organisasi, semakin menarik peran sebuah organisasi sebagai tempat bekerja, semakin mampu sebuah organisasi untuk mendapatkan karyawan berkualitas yang sesuai dengan deskripsi pekerjaan dan standar kinerja yang telah ditetapkan (Gatewood et al., 1993; Lievens et al., 2001; Marin dan Ruiz, 2007).

Penting mengelola daya tarik organisasi, sehingga dapat menarik minat calon pelamar pekerjaan yang memiliki kompetensi unggul dan sesuai dengan kebutuhan organisasi, hal ini mendorong organisasi untuk menginvestigasi faktorfaktor yang mampu meningkatkan reputasi dan daya tarik organisasi tersebut. Fenomena yang terjadi pada perusahaan-perusahaan, baik pada skala internasional maupun nasional, adalah Indonesia diperkirakan akan kekurangan pasokan tenaga kerja profesional di level manajerial atau menengah ke atas ditengah jumlah tenaga kerja Indonesia yang melimpah (SenayanPost.com, 08/06/2017). Dengan kata lain, perusahaan merasa kesulitan mencari tenaga kerja yang memenuhi harapan perusahaan dengan keahlian khusus yang berpotensi mengembangkan perusahaan di masa depan.

Hasil riset Boston Consulting Group (BCG) dan World Federation of People Management Associations (WFPMA) yang dipublikasikan pada 2013 menunjukkan data bahwa terjadi ketimpangan kebutuhan dan ketersediaan tenaga kerja tersebut, terutama di level manajerial (tergambar pada Gambar 1). Menurut 
riset tersebut, industri di Indonesia akan kekurangan hingga 56 persen tenaga kerja profesional di level manajerial pada tahun 2020. Padahal, riset yang sama memperkirakan pada tahun itu ada lonjakan kebutuhan SDM setingkat manajer sampai 55 persen.

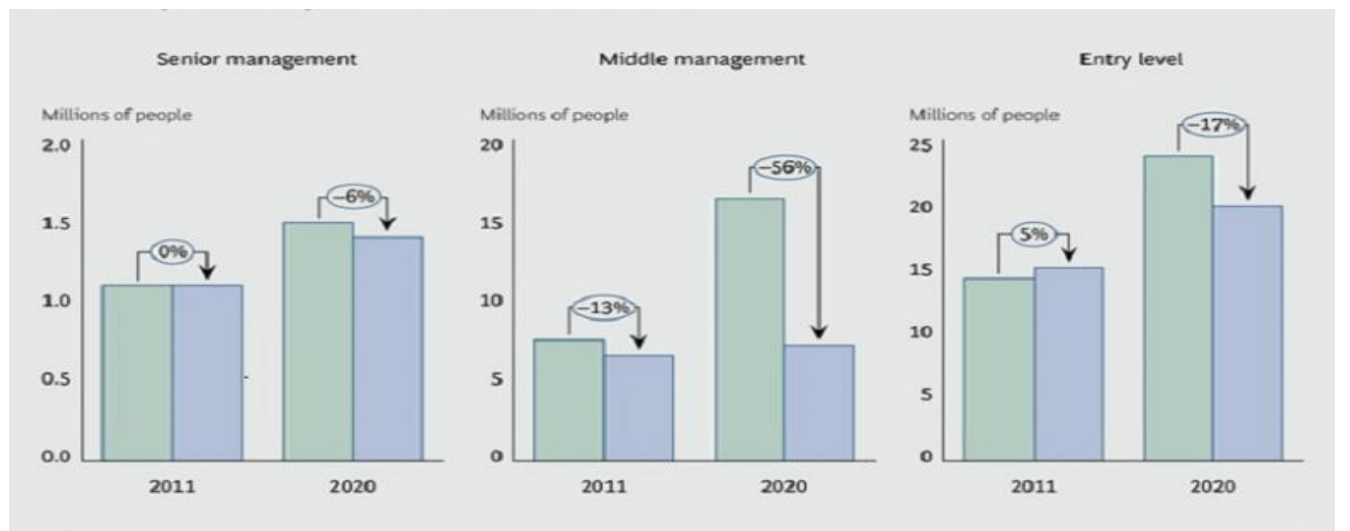

Sumber: Kompas.com, 13 Februari 2017

\section{Gambar 1. Hasil riset BCG dan WFMPA Memprediksi Indonesia}

\section{Kekurangan Tenaga Kerja di Level Menejerial pada tahun 2020}

Fenomena yang terjadi di literatur juga menunjukkan bahwa penelitian yang mengeksplorasi faktor-faktor yang mempengaruhi daya tarik organisasi masih didominasi oleh faktor-faktor yang diturunkan dari keilmuan pemasaran seperti word-of-mouth, kualitas pelayanan, dan corporate social responsibility (Keller,1993; Marin dan Ruiz, 2007; Hoye dan Lievans, 2009). Jika dibandingkan maka dapat dilihat bahwa masih sedikit penelitian yang menginvestigasi peran faktor-faktor yang berbasis pengelolaan SDM di organisasi, seperti keadilan proses seleksi (selection fairness) dan peluang untuk bernegosiasi mengenai masalah gaji (salary negotiation). Selain itu, sejauh ini penelitian mengenai daya tarik organisasi masih didominasi faktor-faktor umum seperti budaya organisasi, 
spesifikasi pekerjaan, jenjang karir, dan proses rekrutmen perusahaan terhadap daya tarik organisasi. Permasalahan yang muncul ini, baik pada praktis maupun literatur, menjadi fenomena negatif yang sebaiknya diperhatikan karena memahami apa yang diinginkan calon pelamar pada suatu organisasi akan menentukan sukses atau tidaknya organisasi tersebut untuk mendapatkan karyawan yang memiliki kompetensi unggul (Tsai dan Irene, 2010; Froese et al., 2010; Lis, 2012).

Keadilan proses seleksi (selection fairness) adalah persepsi calon karyawan tentang keadilan terhadap proses seleksi yang dilakukan oleh perusahaan berkaitan dengan aspek aturan, kejujuran dalam pemilihan karyawan dan hasil seleksi (Gilliland, 1993; Schinkel et al., 2013). Beberapa penelitian sebelumnya mengatakan bahwa persepsi calon karyawan terhadap adil atau tidaknya sebuah proses seleksi akan menarik minat aplikan tersebut untuk melamar di perusahaan. Beberapa penelitian tentang selection fairness terhadap daya tarik organisasi, seperti dari Arvey dan Renz (1992) menyatakan bahwa unsur-unsur prosedural seleksi dan sistem perusahaan dalam membuat keputusan hasil seleksi akan memberi pengaruh terhadap persepsi calon karyawan untuk tertarik melamar di perusahaan tersebut. Bernerth et al. (2005) menyatakan bahwa keterbukaan organisasi dalam proses seleksi baik dalam tes maupun penilaian akan memberikan reaksi positif bagi calon pelamar tertarik terhadap organisasi.

Faktor lainnya yang dapat mempengaruhi daya tarik organisasi adalah terdapatnya kesempatan untuk bernegosiasi mengenai upah yang akan didapat saat proses interview, atau disebut juga salary negotiation. Negosiasi gaji (salary 
negotiation) adalah interaksi antara calon karyawan dan perusahaan dalam bernegosiasi menentukan gaji yang nantinya akan diberikan (Porter et al., 1999; Barber dan Bretz, 2000). Beberapa penelitian sebelumnya, seperti Gerhart dan Rynes (1991) menyatakan bahwa elemen dari proses negosiasi gaji akhirnya mempengaruhi calon karyawan menerima atau menolak tawaran pekerjaan yang diberikan perusahaan. Menurut Adkins et al. (1994) menyatakan bahwa negosiasi gaji penting bagi calon karyawan potensial dan perusahaan untuk mengisi kesenjangan informasi sebelum mulai bekerja. Mazei et al. (2014) menyatakan bahwa perbedaan gender mempengaruhi seseorang dalam bernegosiasi terhadap gaji yang nantinya akan diberikan perusahaan, serta mempengaruhi ketertarikan mereka untuk menerima tawaran tersebut. Negosiasi gaji menjadi aspek yang tidak dapat dipisahkan dalam keberhasilan proses perekrutan calon karyawan.

Setelah hubungan antara dua variabel terbentuk, adalah lazim bagi para peneliti untuk mempertimbangkan variabel mediasi dalam hubungan ini yang dapat memberikan penafsiran yang lebih jelas tentang hubungan antara kedua variabel (Baron dan Kenny, 1986). Faktor-faktor seperti keadilan proses seleksi (selection fairness) dan negosiasi gaji (salary negotiation) yang telah dilakukan perusahaan akan dapat meningkatkan reputasi perusahaan dan tentunya akan menarik minat untuk melamar pekerjaan di organisasi tersebut. Reputasi yang dimiliki perusahaan menjadi pendorong yang kuat untuk daya tarik organisasi (Keller, 1993; Chapman et al., 2005; Barnett et al., 2006). Reputasi perusahaan adalah persepsi dari masing-masing stakeholder secara keseluruhan mengenai seberapa baik respon organisasional yang dilakukan perusahaan (Fomburn, 1996; Wartick, 
2002). Beberapa penelitian sebelumnya, mengenai reputasi perusahaan terhadap daya tarik organisasi, seperti Cable dan Turban (2003) menyatakan bahwa sebelum calon pelamar tertarik bekerja di sebuah perusahaan, hal yang diperhatikan adalah seberapa baik reputasi yang dimiliki oleh perusahaan tersebut. Menurut Williamson et al. (2010) menyatakan bahwa perusahaan yang memiliki reputasi yang baik terutama dalam informasi rekrutmen dan proses seleksi akan memberi pengaruh terhadap daya tarik perusahaan. Dari pemaparan tersebut dapat dilihat reputasi menjadi bagian yang penting bagi daya tarik perusahaan.

Faktor keadilan dalam proses seleksi (selection fairness) dan negosiasi gaji (salary negotiation) akan mempengaruhi kepercayaan calon karyawan terhadap perusahaan dan nantinya akan memberi dampak pada reputasi yang dimiliki perusahaan. Penelitian sebelumnya tentang proses seleksi terhadap daya tarik organisasi, seperti Truxillo et al. (2001) menyatakan bahwa keadilan dalam melakukan tahapan seleksi akan memberikan reaksi positif terhadap reputasi yang dimiliki perusahaan. Ispas et al. (2010) menyatakan bahwa calon pelamar akan sangat memperhatikan proses seleksi yang dilakukan perusahaan sehingga perusahaan harus melakukannya dengan sebaik-baiknya karena akan mempengaruhi reputasi perusahaan terutama perusahaan yang berskala internasional.

Berdasarkan pemaparan diatas dapat diketahui bahwa keadilan proses seleksi dan negosiasi gaji dapat mempengaruhi daya tarik organisasi yang dimediasi oleh faktor reputasi perusahaan. Namun, terkait penelitian ini masih sedikit peneliti yang melakukan penelitian di Indonesia. Hal ini dapat dilihat dari peran negosiasi 
gaji yang jarang diteliti pada penelitian sebelumnya. Penelitian ini bermaksud untuk mengetahui hubungan antara keadilan proses seleksi, negosiasi gaji dan reputasi perusahaan terhadap daya tarik organisasi. Dimana pada saat yang sama peran reputasi perusahaan sebagai faktor mediasi pada daya tarik organisasi juga diuji.

\section{KAJIAN PUSTAKA}

\section{Daya Tarik Organisasi}

Daya tarik organisasi adalah sesuatu yang dimiliki organisasi yang mengacu pada hubungan seseorang memandang keuntungan organisasi tersebut sebagai tempat yang tepat untuk bekerja (Turban dan Keon, 1993). Menurut Schreurs et al. (2009) lebih lanjut mendefinisikan daya tarik organisasi merupakan persepsi dari calon pelamar terhadap karakteristik yang dimiliki oleh oraganisasi. Daya tarik organisasi menjadi sangat penting bagi perusahaan untuk mendapatkan karyawan potensial dan mampu mempersiapkan proses rekrutmen yang baik. Proses rekrutmen yang telah dirancang dengan matang akan mampu menurunkan tingkat turnover karyawan, meningkatkan kinerja organisasi dan mampu menjadi daya tarik organisasi bagi calon karyawan potensial (Lievens et al., 2001).

Beberapa penelitian sebelumnya dapat mengambarkan situasi pustaka tentang daya tarik organisasi, seperti Schreurs et al. (2009) yang meneliti daya tarik organisasi militer di Belgia dengan menggunakan lima faktor kepribadian dari calon karyawan. Ketertarikan dari calon karyawan dipengaruhi oleh persamaan karakteristik mereka terhadap organisasi dan semakin tinggi 
keterbukaan informasi terkait rekrutmen, semakin tinggi semangat calon karyawan melamar di organisasi tersebut. Penelitian dari Anderson et al. (2012) meneliti reaksi dari calon karyawan yang bekerja di Arab Saudi ketika mereka tertarik terhadap sebuah organisasi pada saat proses rekrutmen dan seleksi yang dilakukan perusahaan. Prosedural yang diterapkan organisasi terkait keterbukaan informasi seleksi, tes wawancara dan informasi pekerjaan sangat berpengaruh terhadap daya tarik organisasi.

\section{Reputasi Perusahaan}

Reputasi perusahaan adalah persepsi dari masing-masing stakeholder secara keseluruhan mengenai proses yang dilakukan perusahaan (Fomburn, 1996). Menurut Wartick (2002) mendefinisikan reputasi perusahaan adalah suatu nilai yang diberikan individu terhadap perusahaan mengenai seberapa baik respon organisasional yang telah diterapkan selama ini. Menurut Williamson et al. (2010) mendefinisikan reputasi perusahaan adalah penilaian dari stakeholder terhadap perusahaan dilihat dari kinerja perusahaan.

Beberapa penelitian sebelumnya, mengenai reputasi perusahaan, seperti Cable dan Turban (2003) meneliti bagaimana dan mengapa reputasi perusahaan mempengaruhi pencari kerja dalam ketertarikan mereka bekerja di sebuah organisasi. Sebelum calon pelamar tertarik untuk bekerja di perusahaan, hal yang diperhatikan adalah seberapa baik reputasi yang dimiliki oleh perusahaan tersebut. Penelitian Wiiliamson et al. (2010) meneliti bagaiamana atribut dari perusahaan mempengaruhi reputasi perusahaan. Perusahaan yang memiliki reputasi yang baik 
dalam informasi rekrutmen dan proses seleksi akan memberi pengaruh terhadap daya tarik perusahaan.

\section{Keadilan Proses Seleksi}

Gilliland (1993) mendefinisikan keadilan proses seleksi sebagai persepsi dari calon karyawan tentang keadilan dari proses seleksi yang dilakukan perusahaan terkait prosedur dan hasil seleksi. Menurut Bertolino dan Steiner (2007) mendefinisikan keadilan proses seleksi merupakan keadilan yang dipahami seseorang berdasarkan pada keadilan aturan prosedural seleksi dalam organisasi. Menurut Schinkel et al. (2013) mengemukakan bahwa keadilan proses seleksi adalah reaksi calon karyawan terhadap kejujuran aturan dan hasil dalam proses seleksi yang dilakukan perusahaan.

Beberapa penelitian terkait keadilan proses seleksi, seperti Arvey dan Renz (1992) yang meneliti terkait unsur-unsur keadilan dalam proses seleksi dan pengaruhnya terhadap daya tarik dari calon karyawan. Manajemen harus dapat memperhatikan proses seleksi yang dilakukan agar banyak calon karyawan potensial tertarik untuk mengikuti seleksi. Hasil dari seleksi sangat penting bagi perusahaan dalam jangka panjang terutama dalam mendapatkan calon karyawan yang diinginkan, sehingga tujuan perusahaan dapat tercapai. Penelitian lainnya, Bertolino dan Steiner (2007) yang melakukan penelitian terhadap mahasiswa yang ada di Italia, mereka diminta untuk menilai prosedur seleksi yang telah dilakukan baik tes tertulis, wawancara dan hasil seleksi dan dampaknya ketertarikan mereka untuk masuk di universitas tersebut. Keadilan terkait proses yang dilakukan dalam 
seleksi tersebut sangat menjadi pedoman mereka untuk masuk di universitas tersebut.

\section{Negosiasi Gaji}

Menurut Porter et al. (1999) mendefinisikan negosiasi gaji adalah interaksi yang dilakukan calon karyawan terhadap perusahaan dalam negosiasi jumlah gaji yang diinginkan. Menurut Barber dan Bretz (2000) mendefinisikan negosiasi gaji merupakan segala usaha yang dilakukan untuk mendapatkan kesepakatan bersama antara calon karyawan dan tempat mereka bekerja nantinya terkait gaji yang akan diberikan perusahaan. Menurut Leibbrandt dan List (2012) mendefinisikan negosiasi gaji adalah adanya kesamaan keinginan calon karyawan dan perusahaan tempat bekerja terkait gaji yang nantinya diberikan atas keputusan bersama.

Beberapa penelitian sebelumnya, seperti Gerhart dan Rynes (1991) meneliti elemen dari proses negosiasi gaji mempengaruhi calon karyawan menerima atau menolak tawaran pekerjaan yang diberikan perusahaan. Aspek yang menarik calon karyawan yang sering diabaikan adalah tawaran yang diberikan kepada calon karyawan yang baru lulus sarjana, durasi waktu kesepakatan yang kurang diperhatikan, dan bonus yang akan diberikan. Penelitian yang dilakukan Adkins et al. (1994) meneliti negosiasi gaji penting bagi calon karyawan potensial dan perusahaan untuk mengisi kesenjangan informasi sebelum mulai bekerja. Keterbukaan mengenai informasi gaji sangat dibutuhkan calon karyawan untuk dapat tertarik terhadap sebuah organisasi. 


\section{Model Konseptual}

Pemaparan pustaka diatas menunjukkan sebuah gambaran umum bahwa terdapat pengaruh keadialan proses seleksi dan negosiasi gaji terhadap daya tarik organisasi dengan reputasi perusahaan sebagai variabel mediasi. Pada gambar 2 dapat dilihat model konseptual penelitian sebagai berikut:

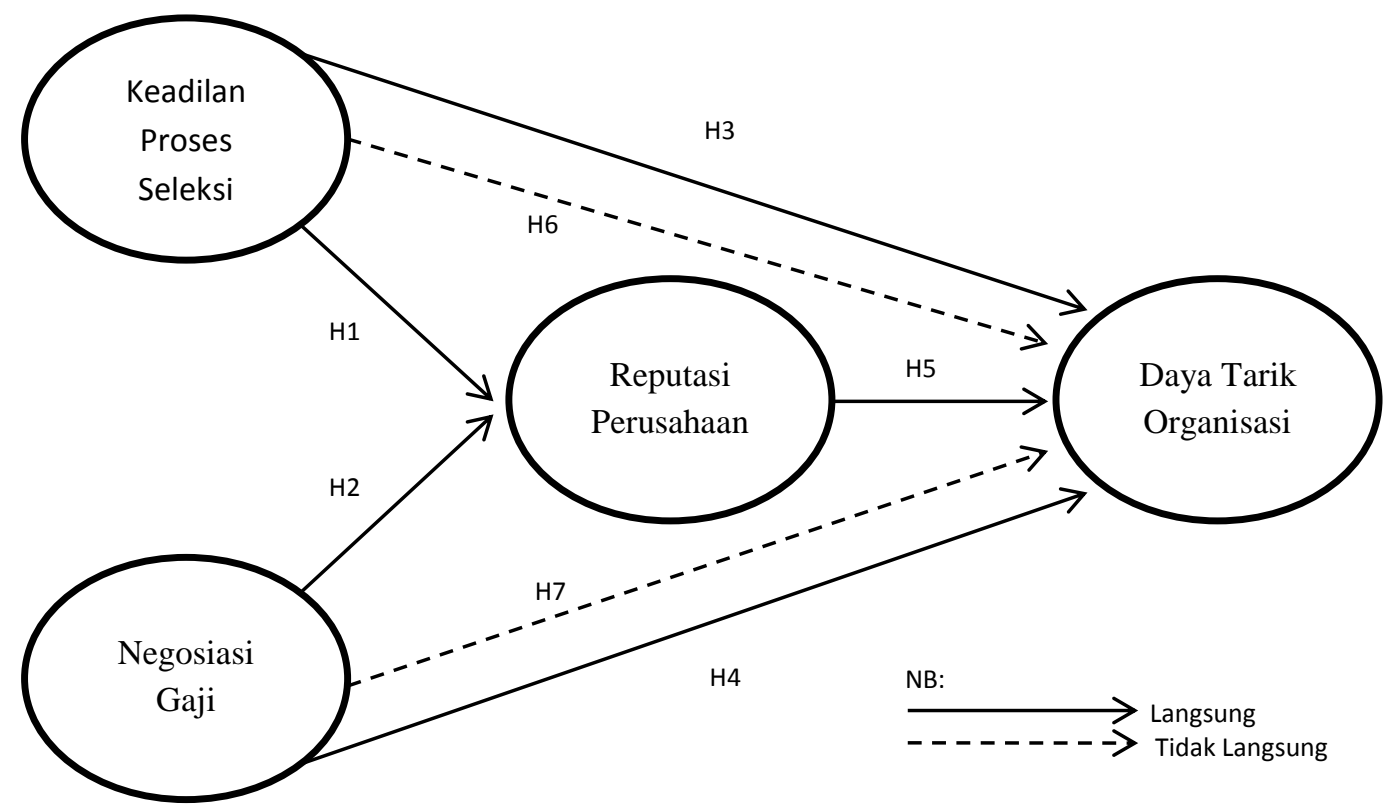

Gambar 2. Model Konseptual Penelitian

Sumber: Pengembangan dari penelitian sebelumnya

\section{METODE PENELITIAN}

Penelitian ini dilakukan pada sekolah TK, SD, SMP dan SMA yang berada di Yayasan Insan Mandiri Denpasar dengan mengambil subjek para guru tetap dan guru tidak tetap TK, SD, SMP dan SMA Santo Yoseph Denpasar yang tersebar pada 6 Sekolah yaitu TKK Santo Yoseph Denpasar, TKK Santo Yoseph 1 
Denpasar, SDK Santo Yoseph 1 Denpasar, SDK Santo Yoseph 2 Denpasar, SMP Santo Yoseph Denpasar dan SMA Santo Yoseph Denpasar. Teknik pengumpulan sampel yang digunakan pada penelitian ini adalah teknik sampling proporsional karena populasi dianggap mempunyai probability yang sama untuk menjadi sampel dalam penelitian ini. Untuk menentukan jumlah sampel yang akan digunakan, maka peneliti menggunakan rumus Slovin, dan diperoleh proporsi sampel yang ditunjukkan pada Tabel 1. Untuk memperoleh data yang akan diteliti, peneliti menggunakan teknik pengumpulan data dengan menggunakan kuesioner. Adapun beberapa instrumen pertanyaan kuisioner seperti "Saya memilih bekerja pada sekolah yang memiliki reputasi yang baik" dan "Saya ingin tes seleksi yang dilakukan organisasi sesuai konten yang relevan”. Setelah kuisioner disebarkan, kemudian data penelitian dianalisis dengan menggunakan analisis Partial Least Square (PLS).

\section{Tabel 1}

Distribusi Sampel Guru Tetap dan Tidak Tetap TK, SD, SMP, dan SMA Santo Yoseph Denpasar

\begin{tabular}{clcc}
\hline No. & \multicolumn{1}{c}{ Nama Sekolah } & Jumlah Populasi & Jumlah Sampel \\
\hline 1 & TKK Santo Yoseph & 9 & $9 / 114 \times 53=4$ \\
2 & TKK Santo Yoseph 1 & 4 & $4 / 114 \times 53=2$ \\
3 & SDK Santo Yoseph 1 & 22 & $22 / 114 \times 53=10$ \\
4 & SDK Santo Yoseph 2 & 17 & $17 / 114 \times 53=8$ \\
5 & SMP Santo Yoseph & 27 & $27 / 114 \times 53=13$ \\
6 & SMA Santo Yoseph & 35 & $35 / 114 \times 53=16$ \\
\multicolumn{2}{c}{ Jumlah Sampel } & & 53 \\
\hline
\end{tabular}
Sumber: Hasil Pengolahan Data 


\section{HASIL DAN PEMBAHASAN}

\section{Karakteristik Responden}

Adapun karateristik demografi guru tetap dan tidak tetap (responden) di sekolah-sekolah regio Santo Yoseph yang diperoleh dari hasil pengolahan data kuesioner adalah seperti yang ditampilkan dalam Tabel 2.

Tabel 2

\section{Karakteristik Responden}

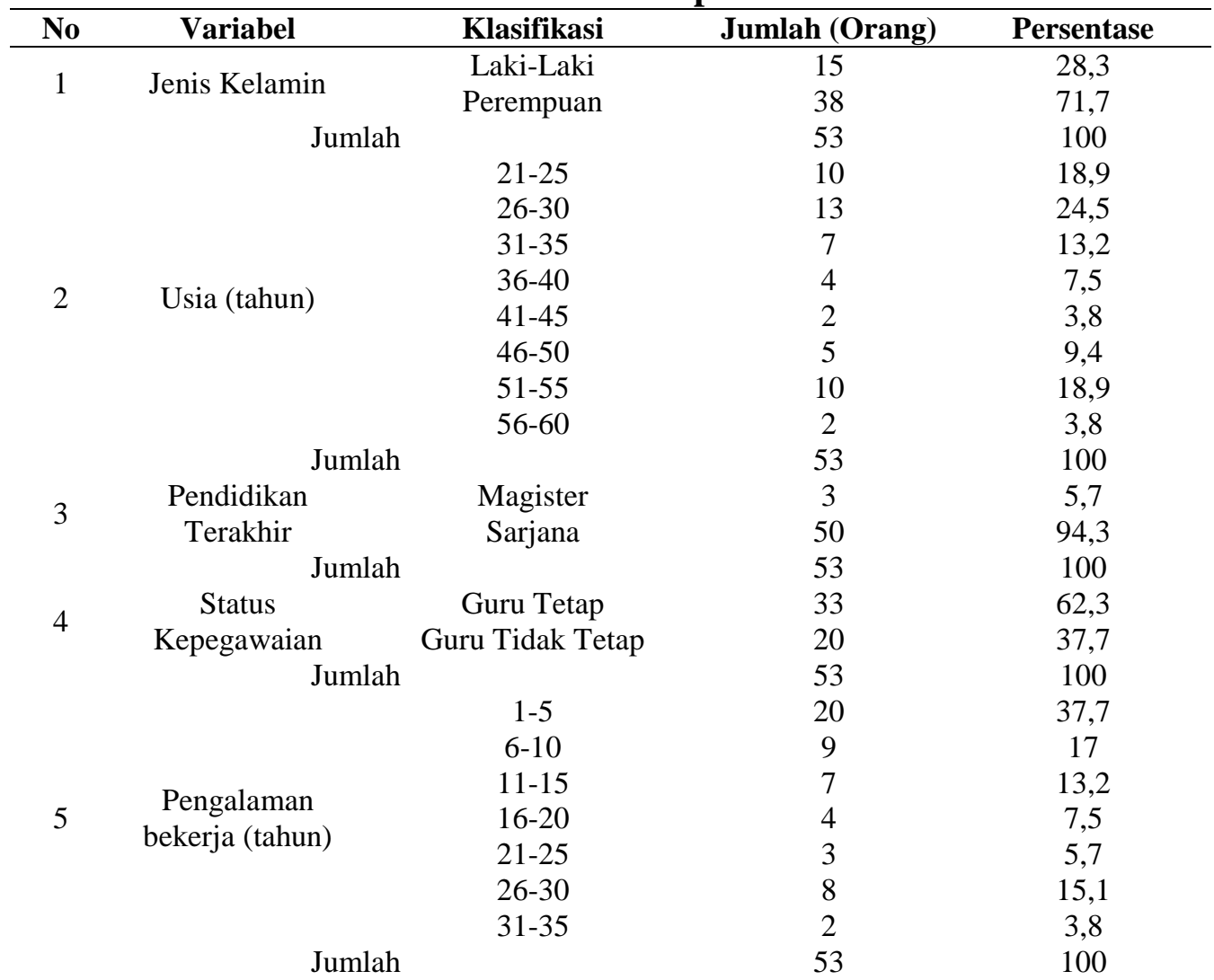

Sumber: Data diolah

Ringkasan pada Tabel 2 menunjukkan bahwa kuesioner yang telah disebarkan kepada para responden didominasi oleh perempuan sebanyak 71,7 persen, sedangkan laki-laki sebanyak 28,3 persen Berdasarkan usia, didominasi oleh usia 26 sampai 30 tahun sebanyak 24,5 persen dan responden yang jumlah paling sedikit adalah usia 56 sampai 60 tahun sebanyak 3,8 persen. Pada 
pengelompokkan berdasarkan pendidikan terakhir, responden yang sarjana lebih mendominasi sebesar 94,3 persen dan responden yang magister hanya 5,7 persen. Responden dalam penelitian ini yang merupakan guru tetap sebanyak 62,3 persen, sedangkan guru tidak tetap sebanyak 37,7 persen. Terakhir, pengelompokkan berdasarkan pada pengalaman bekerja responden yang paling banyak persetasenya adalah bekerja mulai 1-5 tahun bekerja sebanyak 37,7 persen, sedangkan persentase responden yang pengalaman bekerja paling sedikit ada pada pengalaman bekerja 31 sampai 35 tahun yaitu sebanyak 3,8 persen.

\section{Hasil Pengujian Instrumen Penelitian}

Pengujian instrument penelitian menggunakan uji validitas dan uji reliabilitas sebagai berikut.

\section{1) Uji Validitas}

Suatu instrument dikatakan valid jika korelasi antara skor faktor dengan skor total bernilai positif dan nilainya lebih besar dari 0,50 (r>0,50). Adapun hasil dari uji validitas dapat ditunjukkan pada Tabel 3

Berdasarkan hasil uji validitas, diketahui bahwa uji validitas dari variabel daya tarik organisasi yang memiliki korelasi terbesar yaitu persaman pandangan (Y2.4) yang bernilai 0,964, dan tingkat korelasi terbesar dari variabel reputasi perusahaan adalah meningkatnya kinerja organisasi (Y1.2) yang bernilai 0,977, sedangkan pada variabel keadilan proses seleksi yang memiliki korelasi tertinggi adalah komunikasi dua arah (X1.9) yang bernilai 0,898, dan pada variabel negosiasi gaji yang memiliki korelasi terbesar yaitu perusahaan memberikan respon yang baik terhadap proses negosiasi gaji (X2.1) yang bernilai 0,949. 
Tabel 3

Hasil Uji Validitas

\begin{tabular}{|c|c|c|c|}
\hline Variabel & Indikator & $\begin{array}{c}\text { Koefisien } \\
\text { Korelasi } \\
\text { (r hitung) }\end{array}$ & korelasi \\
\hline \multirow{6}{*}{$\begin{array}{c}\text { Daya Tarik } \\
\text { Organisasi } \\
\text { (Y2) }\end{array}$} & Pilihan pekerjaan dan karakteristik organisasi (Y2.1) & 0,912 & Valid \\
\hline & Karakteristik perekrut (Y2.2) & 0,919 & Valid \\
\hline & Persepsi tentang proses rekrutmen (Y2.3) & 0,933 & Valid \\
\hline & Persamaan pandangan (Y2.4) & 0,964 & Valid \\
\hline & Adanya kesempatan kerja alternatif (Y2.5) & 0,776 & Valid \\
\hline & Adanya pengembangan karir yang baik (Y2.6) & 0,945 & Valid \\
\hline Reputasi & Membentuk kepercayaan stakeholder (Y1.1) & 0,971 & Valid \\
\hline \multirow{5}{*}{$\begin{array}{l}\text { Perusahaan } \\
\text { (Y1) }\end{array}$} & Meningkatnya kinerja organisasi (Y1.2) & 0,977 & Valid \\
\hline & Mampu mengembangkitkan rasa bangga (Y2.3) & 0,966 & Valid \\
\hline & Keterkaitan pekerjaan yang relevan (X1.1) & 0,867 & Valid \\
\hline & Kesempatan untuk melakukan keseluruhan tahapan seleksi (X1.2) & 0,806 & Valid \\
\hline & Kesempatan peninjauan kembali (X1.3) & 0,846 & Valid \\
\hline \multirow{8}{*}{$\begin{array}{c}\text { Keadilan } \\
\text { Proses } \\
\text { Seleksi (X1) }\end{array}$} & Konsistensi perusahaan dalam proses seleksi (X1.4) & 0,853 & Valid \\
\hline & Umpan balik (X1.5) & 0,750 & Valid \\
\hline & Adanya informasi tahapan seleksi yang jelas (X1.6) & 0,791 & Valid \\
\hline & Keterbukaan informasi (X1.7) & 0,834 & Valid \\
\hline & Perlakuan saat tes seleksi (X1.8) & 0,785 & Valid \\
\hline & Komunikasi dua arah (X1.9) & 0,898 & Valid \\
\hline & Kepatutan pertanyaan (X1.10) & 0,837 & Valid \\
\hline & Perusahaan memberikan respon yang baik terhadap proses negosiasi gaji (X2.1) & 0,949 & Valid \\
\hline \multirow{2}{*}{$\begin{array}{l}\text { Negosiasi } \\
\text { Gaji (X2) }\end{array}$} & $\begin{array}{l}\text { Adanya kejelasan informasi dan keterbukaan dalam prosedur penetapan gaji } \\
(\mathrm{X} 2.2)\end{array}$ & 0,908 & Valid \\
\hline & Keadilan dalam proses negosiasi gaji (X2.3) & 0,952 & Valid \\
\hline
\end{tabular}

Sumber: Data diolah

Dapat disimpulkan bahwa hasil uji validitas yang telah dilakukan dengan

menggunakan kuesioner dalam penelitian ini dapat dikatakan valid, dimana nilai dari masing-masing indikator terdapat korelasi.

\section{2) Uji Reliabilitas}

Uji reliabilitas merupakan alat yang digunakan untuk mengetahui ketepatan jawaban kuesioner pada periode yang berbeda. Pengujian statistik ini dengan menggunakan teknik statistik cronbach's alpha. Hasil dari pengujian reliabiltas dapat dilihat pada Tabel 4 
Tabel 4

Hasil Uji Reliabilitas

\begin{tabular}{clcc}
\hline No & \multicolumn{1}{c}{ Variabel } & $\begin{array}{c}\text { Cronbach } \\
\text { Alpha }\end{array}$ & Keterangan \\
\hline 1 & Daya Tarik Organisasi (Y2) & 0,957 & Reliabel \\
2 & Reputasi Perusahaan (Y1) & 0,970 & Reliabel \\
3 & Keadilan Proses Seleksi (X1) & 0,969 & Reliabel \\
4 & Negosiasi Gaji (X2) & 0,930 & Reliabel \\
\hline & Sumber: Data diolah & &
\end{tabular}

Hasil pengujian pada tabel 4.4 menunjukkan bahwa seluruh penelitian memiliki nilai koefisien korelasi Cronbach Alpha lebih besar 0,70 sehingga seluruh variabel dikatakan reliabel, maka instrumen dapat dilanjutkan.

\section{Analisis Model Penelitian dengan Metode PLS}

\section{1) Evaluasi Model Pengukuran atau Outer Model}

Dalam mengevaluasi outer model digunakan tiga kriteria yaitu, convergent validity, discriminant validity dan composite reliability. Evaluasi model pengukuran berdasarkan outer loading untuk indikator reflektif dengan kriteria, yaitu indikator reflektif dianggap valid jika memiliki nilai loading diatas 0,50 dan atau nilai t-statistik diatas 1,96 yang artinya model tersebut memiliki convergent validity.

\section{a. Convergent Validity}

Berikut ini adalah hasil pengujian convergent validity dari indikatorindikator daya tarik organisasi, reputasi perusahaan, keadilan proses seleksi dan negosiasi gaji yang disajikan pada Tabel 5 
Tabel 5

Outer Loading Variabel Penelitian

\begin{tabular}{lcc}
\hline & $\begin{array}{c}\text { Original Sample } \\
(\mathbf{O})\end{array}$ & $\begin{array}{c}\text { T Statistics } \\
(\mid \mathbf{O} / \mathbf{S T D E V})\end{array}$ \\
\hline X1.1 <-- Keadilan Proses Seleksi & 0,903 & 42,868 \\
X1.10 <-- Keadilan Proses Seleksi & 0,868 & 24,607 \\
X1.2 <-- Keadilan Proses Seleksi & 0,877 & 29,976 \\
X1.3 <-- Keadilan Proses Seleksi & 0,893 & 38,958 \\
X1.4 <-- Keadilan Proses Seleksi & 0,912 & 43,014 \\
X1.5 <-- Keadilan Proses Seleksi & 0,834 & 21,271 \\
X1.6 <-- Keadilan Proses Seleksi & 0,844 & 23,718 \\
X1.7 <-- Keadilan Proses Seleksi & 0,924 & 44,699 \\
X1.8 <-- Keadilan Proses Seleksi & 0,822 & 21,072 \\
X1.9 <-- Keadilan Proses Seleksi & 0,904 & 33,966 \\
X2.1 <-- Negosiasi Gaji & 0,951 & 79,113 \\
X2.2 <-- Negosiasi Gaji & 0,923 & 46,181 \\
X2.3 <-- Negosiasi Gaji & 0,968 & 89,914 \\
Y1.1 <-- Reputasi Perusahaan & 0,974 & 112,447 \\
Y1.2 <-- Reputasi Perusahaan & 0,979 & 205,525 \\
Y1.3 <-- Reputasi Perusahaan & 0,961 & 98,188 \\
Y2.1 <-- Daya Tarik Organisasi & 0,911 & 33,979 \\
Y2.2 <-- Daya Tarik Organisasi & 0,927 & 53,134 \\
Y2.3 <-- Daya Tarik Organisasi & 0,921 & 47,241 \\
Y2.4 <-- Daya Tarik Organisasi & 0,937 & 32,907 \\
Y2.5 <-- Daya Tarik Organisasi & 0,747 & 11,985 \\
Y2.6 <-- Daya Tarik Organisasi & 0,914 & 25,601 \\
\hline
\end{tabular}

Sumber: Data diolah

Berdasarkan Tabel 5 menunjukkan bahwa hasil output dari semua indikator-indikator reflektif dianggap valid dan telah memenuhi convergent validity karena nilai loading diatas 0,50 dan atau nilai tstatistik diatas 1,96 .

b. Discriminant Validity

Evaluasi model pengukuran berdasarkan cross loading digunakan untuk menilai apakah konstruk memiliki discriminant validity yang baik. Discriminant validity dianggap valid apabila memiliki cross loading setiap indikator pada variabel bersngkutan memiliki nilai 
terbesar dibandingkan cross loading variabel laten lainnya. Hasil cross loading dari ketiga variabel disajikan pada Tabel 6

Tabel 6

Hasil Perhitungan Cross Loading

\begin{tabular}{ccccc}
\hline & $\begin{array}{c}\text { Daya Tarik } \\
\text { Organisasi }\end{array}$ & $\begin{array}{c}\text { Keadilan Proses } \\
\text { Seleksi }\end{array}$ & Negosiasi Gaji & $\begin{array}{c}\text { Reputasi } \\
\text { Perusahaan }\end{array}$ \\
\hline X1.1 & 0,707 & $\mathbf{0 , 9 0 3}$ & 0,680 & 0,651 \\
X1.10 & 0,695 & $\mathbf{0 , 8 6 8}$ & 0,719 & 0,675 \\
X1.2 & 0,711 & $\mathbf{0 , 8 7 7}$ & 0,677 & 0,710 \\
X1.3 & 0,751 & $\mathbf{0 , 8 9 3}$ & 0,732 & 0,704 \\
X1.4 & 0,776 & $\mathbf{0 , 9 1 2}$ & 0,725 & 0,702 \\
X1.5 & 0,681 & $\mathbf{0 , 8 3 4}$ & 0,581 & 0,652 \\
X1.6 & 0,633 & $\mathbf{0 , 8 4 4}$ & 0,671 & 0,637 \\
X1.7 & 0,708 & $\mathbf{0 , 9 2 4}$ & 0,704 & 0,661 \\
X1.8 & 0,634 & $\mathbf{0 , 8 2 2}$ & 0,604 & 0,595 \\
X1.9 & 0.692 & 0,904 & 0,697 & 0,669 \\
X2.1 & 0,767 & 0,682 & $\mathbf{0 , 9 5 1}$ & 0,772 \\
X2.2 & 0,754 & 0,743 & $\mathbf{0 , 9 2 3}$ & 0,707 \\
X2.3 & 0,814 & 0,731 & $\mathbf{0 , 9 5 8}$ & 0,748 \\
Y1.1 & 0,827 & 0,727 & 0,761 & $\mathbf{0 , 9 7 4}$ \\
Y1.2 & 0,841 & 0,752 & 0,724 & $\mathbf{0 , 9 7 9}$ \\
Y1.3 & 0,867 & 0,779 & 0,804 & $\mathbf{0 , 9 6 1}$ \\
Y2.1 & $\mathbf{0 , 9 1 1}$ & 0,759 & 0,794 & 0,799 \\
Y2.2 & $\mathbf{0 , 9 2 7}$ & 0,735 & 0,763 & 0,812 \\
Y2.3 & $\mathbf{0 , 9 2 1}$ & 0,741 & 0,791 & 0,871 \\
Y2.4 & $\mathbf{0 , 9 3 7}$ & 0,584 & 0,730 & 0,764 \\
Y2.5 & $\mathbf{0 , 7 4 7}$ & 0,667 & 0,617 & 0,656 \\
Y2.6 & $\mathbf{0 , 9 1 4}$ & 0,721 & 0,757 \\
\hline
\end{tabular}

Sumber: Data diolah

Berdasarkan Tabel 6 dapat dilihat bahwa cross loading yang diperoleh masing-masing varibabel laten lebih tinggi dibandingkan dengan variabel laten lainnya sehingga dapat dikatakan bahwa variabel laten telah memenuhi dicriminant validity, dapat dilihat bahwa korelasi konstruk daya tarik organisasi (Y2) dengan indikatornya lebih tinggi dibandingkan korelasi dengan indikator keadilan proses seleksi (X1), negosiasi gaji (X2), dan reputasi perusahaan (Y1). Korelasi konstruk keadilan proses seleksi (X1) dengan indikatornya lebih tinggi dibandingkan korelasi dengan indikator negosiasi gaji (X2), reputasi 
perusahaan (Y1), dan daya tarik organisasi (Y2). Korelasi negosiasi gaji (X2) dengan indikatornya lebih tinggi dibandingkan korelasi dengan indikator keadilan proses seleksi (X1), reputasi perusahaan (Y1), dan daya tarik organisasi (Y2). Korelasi konstruk reputasi perusahaan (Y1) dengan indikatornya lebih tinggi dibandingkan korelasi dengan indikator keadilan proses seleksi (X1), negosiasi gaji (X2), dan daya tarik organisasi (Y2). Cara lain untuk menilai discriminant validity adalah dengan membandingkan akar kuadrat dari average variance extracted untuk setiap konstruk dengan konstruk lainnya dalam model. Model mempunyai discriminant validity yang cukup jika akar AVE untuk setiap konstruk lebih besar dari korelasi antara konstruk dan konstruk lainnya dalam model seperti yang terlihat pada Tabel 7

Tabel 7

Perbandingan Akar Kuadrat Average Variance Extracted dengan Latent Variable Correlations

\begin{tabular}{lcccccc}
\hline \multicolumn{1}{c}{ Variabel Penelitian } & AVE & $\sqrt{ }$ AVE & $\begin{array}{c}\text { Korelasi } \\
\text { Daya Tarik } \\
\text { Organisasi } \\
\text { (Y2) }\end{array}$ & $\begin{array}{c}\text { Keadilan } \\
\text { Proses } \\
\text { Seleksi } \\
\text { (X1) }\end{array}$ & $\begin{array}{c}\text { Negosiasi } \\
\text { Gaji (X2) }\end{array}$ & $\begin{array}{c}\text { Reputasi } \\
\text { Perusahaan } \\
\text { (Y1) }\end{array}$ \\
\hline Daya Tarik Organisasi (Y2) & 0,802 & 0,895 & 1,000 & & & \\
Keadilan Proses Seleksi (X1) & 0,772 & 0,878 & 0,797 & 1,000 & \\
Negosiasi Gaji (X2) & 0,891 & 0,943 & 0,825 & 0,774 & 1,000 & 1,000 \\
Reputasi Perusahaan (Y1) & 0,943 & 0,971 & 0,871 & 0,759 & 0,787 & \\
\hline
\end{tabular}

Sumber: Data diolah

Pada Tabel 7 dapat dijelaskan bahwa semua variabel memiliki nilai AVE di atas 0.50 , dan nilai $\sqrt{ }$ AVE untuk setiap variabel lebih tinggi didandingkan dengan korelasi antar variabel. Hasil tersebut mengindikasikan bahwa variabel laten indikatornya sendiri lebih baik 
dari indikator variabel laten lainnya. Berdasarkan hasil analisis ini dapat dikatakan data memiliki discriminant validity yang baik.

\section{c. Composite Reliability}

Reliabilitas konstruk dari measurement model dengan indikator reflektif dapat diukur dengan melihat nilai composite reliability dan diperkuat dengan nilai cronbach's alpha. Nilai composite reliability dan cronbach's alpha yang baik apabila memiliki nilai $\geq$ 0,70 (Wiyono, 2011:403). Berikut adalah hasil penelitian reliabilitas instrument yang di sajikan pada Tabel 8

\section{Tabel 8}

Composite Relibility

\begin{tabular}{clccc}
\hline No & \multicolumn{1}{c}{ Variabel } & $\begin{array}{c}\text { Composite } \\
\text { Reliability }\end{array}$ & $\begin{array}{c}\text { Cronbachs } \\
\text { Alpha }\end{array}$ & Keterangan \\
\hline 1 & Daya Tarik Organisasi & 0,960 & 0,949 & Reliabel \\
2 & Keadilan Proses Seleksi & 0,971 & 0,967 & Reliabel \\
3 & Negosiasi Gaji & 0,961 & 0,939 & Reliabel \\
4 & Reputasi Perusahaan & 0,980 & 0,970 & Reliabel \\
\hline
\end{tabular}

Sumber data diolah

Berdasarkan pada Tabel 8 menunjukkan bahwa, nilai composite reliability maupun nilai cronbachs alpha untuk semua konstruk memiliki nilai lebih dari 0,7. Dengan demikian pada model penelitian, masing-masing konstruk penelitian memenuhi reliabilitas yang baik.

\section{2) Evaluasi Model Struktur atau Inner Model}

Pengujian inner model atau model struktural dilakukan untuk melihat hubungan antara konstruk, nilai signifikansi dan $R$-square dari 
model penelitian. Adapun hasil dari pengujian inner model dapat dilihat pada Gambar 3 sebagai berikut.

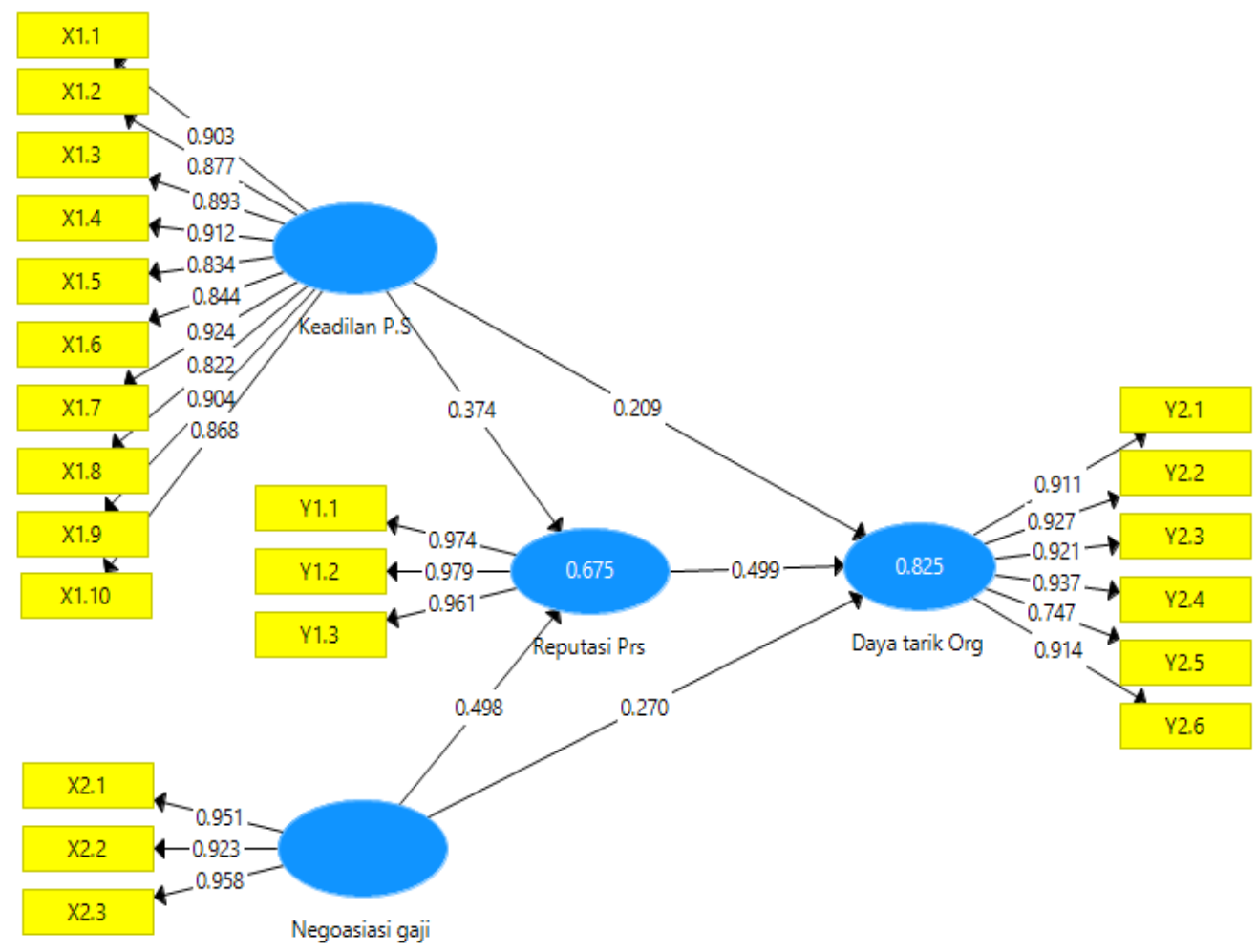

Gambar 3

\section{Model Struktural}

Model struktural dievaluasi dengan menggunakan $R$-square untuk konstruk dependen dan uji $t$ serta signifikansi dari koefisien parameter jalur structural.

Tabel 9

R-square

\begin{tabular}{lc}
\multicolumn{1}{c}{ Konstruk } & R-square \\
\hline Daya Tarik Organisasi & 0,825 \\
Reputasi Perusahaan & 0,675 \\
\hline \multicolumn{1}{c}{ Sumber: Data diolah } &
\end{tabular}


Selain menggunakan $R$-square, goodness of fit, model juga diukur dengan menggunakan Q-Square predicat relevance untuk model struktural, mengukur seberapa baik obeservasi yang dihasilkan oleh model dan juga estimasi parameternya. Nilai $Q$-Squre $>0$ menunjukkan model memiliki predicate relevance, sebaliknya jika nilai $Q$-Square $\leq 0$ menunjukkan model tidak memiliki predicate relevance. Berdasarkan Tabel 5.12 dapat dihitung nilai predicat relevance $\left(Q^{2}\right)$, yaitu:

$$
\begin{aligned}
Q^{2} & =1-\left(1-R 1^{2}\right)\left(1-R 2^{2}\right) \\
& =1-(1-0,825)(1-0,675) \\
& =1-(0,175)(0,325) \\
& =1-0,056 \\
& =0,943
\end{aligned}
$$

Hasil perhitungan ini menunjukkan bahwa nilai $Q^{2}$ lebih besar dari 0 (0,943), sehingga dapat diinterpretasikan bahwa model baik karena memiliki nilai prediktif yang relevan, yaitu sebesar 94,3\% variasi pada variabel daya tarik organisasi mampu dijelaskan oleh variabel-variabel yang digunakan yaitu variabel keadilan proses seleksi, negosiasi gaji dan reputasi perusahaan, sedangkan sisanya 5,7 \% dijelaskan oleh variabel lain yang belum masuk ke dalam model.

\section{3) Hasil Koefisien Jalur dan t-statistik}

Berdasarkan perhitungan PLS yang telah dilakukan, diketahui bahwa besarnya pengaruh langsung, pengaruh tidak langsung dan 
pengaruh total antar variabel. Perhitungan pengaruh antar variabel dapat dilihat pada Tabel 10

Tabel 10

Pengaruh Langsung, Pengaruh Tidak Langsung dan Pengaruh Total Variabel

\begin{tabular}{lcc}
\hline \multicolumn{1}{c}{ Variabel } & \multicolumn{2}{c}{ Pengaruh Langsung } \\
& Koefisien & $\begin{array}{c}\text { T Statistik } \\
(\mid \mathbf{O} / \text { STEV } \mid)\end{array}$ \\
\hline Keadilan Proses Seleksi -> Daya Tarik Organisasi & 0,209 & 2,223 \\
Keadialan Proses Seleksi -> Reputasi Perusahaan & 0,374 & 2,588 \\
Negosiasi Gaji -> Daya Tarik Organisasi & 0,270 & 2,501 \\
Negosiasi Gaji -> Reputasi Perusahaan & 0,498 & 3,295 \\
Reputasi Perusahaan -> Daya Tarik Organisasi & 0,499 & 3,789 \\
\multicolumn{1}{c}{ Variabel } & Pengaruh Tidak Langsung \\
Keadilan Proses Seleksi -> Daya Tarik Organisasi & 0,187 & 2,042 \\
Negosiasi Gaji -> Daya Tarik Organisasi & 0,249 & 2,438 \\
Variabel & Pengaruh Total \\
Keadilan Proses Seleksi -> Daya Tarik Organisasi & 0,395 & 4,196 \\
Negosiasi Gaji -> Daya Tarik Organisasi & 0,519 & 4,934 \\
Reputasi Perusahaan -> Daya Tarik Organisasi & 0,499 & 3,789 \\
\hline
\end{tabular}

Sumber: Data Diolah

Pada Tabel 10 dapat dilihat bahwa keadilan proses seleksi memiliki pengaruh langsung terhadap daya tarik organisasi sebesar 0,209. Keadilan proses seleksi memiliki pengaruh langsung terhadap reputasi perusahaan sebesar 0,374 . Negosiasi gaji memiliki pengaruh langsung terhadap daya tarik organisasi sebesar 0,270. Negosiasi gaji memiliki pengaruh langsung terhadap reputasi perusahaan sebesar 0,498. Kemudian, reputasi perusahaan memiliki pengaruh langsung terhadap daya tarik organisasi sebesar 0,499 . Pengaruh tidak langsung antara keadilan proses seleksi terhadap daya tarik organisasi sebesar 0,187, sedangkanm 
pengaruh tidak langsung negosiasi gaji terhadap daya tarik organisasi sebesar 0,249. Adapun pengaruh total yang dimiliki antara keadilan proses seleksi terhadap daya tarik organisasi sebesar 0,395. Pengaruh total antara negosiasi gaji terhadap daya tarik organisasi sebesar 0,519 dan pengaruh total reputasi perusahaan terhadap daya tarik organisasi sebesar 0,499 .

\section{4) Pengujian Hipotesis}

Signifikansi parameter yang diestimasi memberikan informasi yang sangat berguna mengenai hubungan antara variabel-variabel penelitian. Dasar yang digunakan dalam menguji hipotesis adalah nilai yang terdapat pada output path coeficients yang di sajikan pada Tabel 11 di bawah ini.

Tabel 11

Path Coefficients

\begin{tabular}{lccc}
\hline \multicolumn{1}{c}{ Konstruk } & $\begin{array}{c}\text { Koefisien } \\
\text { Korelasi }\end{array}$ & t statistics & Keterangan \\
\hline Keadilan Proses Seleksi -> Daya Tarik Organisasi & 0,209 & 2,223 & Diterima \\
Keadilan Proses Seleksi -> Reputasi Perusahaan & 0,374 & 2,588 & Diterima \\
Negosiasi Gaji -> Daya Tarik Organisasi & 0,270 & 2,501 & Diterima \\
Negosiasi Gaji -> Reputasi Perusahaan & 0,498 & 3,295 & Diterima \\
Reputasi Perusahaan -> Daya Tarik Organisasi & 0,499 & 3,789 & Diterima \\
\hline \multicolumn{1}{c}{ Sumber: Data diolah } & & &
\end{tabular}

Pengujian hipotesis dilakukan dengan menggunakan t-statistics. Apabila nilai t-statistics $\geq$ nilai t-tabel $(1,96)$, maka Ho ditolak dan hipotesis penelitian diterima. Berdasarkan pada Tabel 11 dapat dilihat bahwa hipotesis pada penelitian ini seluruhnya diterima. Berdasarkan data yang diperoleh pada Tabel 11 menunjukkan bahwa pengaruh keadilan 
proses seleksi terhadap reputasi perusahaan memiliki path coefficient sebesar 0,374 dengan nilai t-statistics sebesar 2,588. Nilai t-statistics tersebut lebih besar dari nilai t-tabel yaitu 1,96 yang dapat diinterpretasikan adanya pengaruh positif dan signifikan antara variabel keadilan proses seleksi dan reputasi perusahaan. Path coefficient menunjukkan bahwa keadilan proses seleksi memberikan pengaruh positif terhadap reputasi perusahaan. Hal ini berarti bahwa semakin tinggi keadilan proses seleksi, maka semakin tinggi pula tingkat reputasi yang dimiliki perusahaan.

Pengaruh negosiasi gaji terhadap reputasi perusahaan memiliki path coefficient sebesar 0,498 dengan nilai t-statistics sebesar 3,295. Nilai $t$ statistics tersebut lebih besar dari nilai t-tabel yaitu 1,96 yang dapat diinterpretasikan adanya pengaruh positif dan signifikan antara variabel negosiasi gaji dan reputasi perusahaan. Path coefficient menunjukkan bahwa negosiasi gaji memberikan pengaruh positif terhadap reputasi perusahaan. Hal ini berarti bahwa semakin tinggi negosiasi gaji, maka semakin tinggi pula tingkat reputasi yang dimiliki perusahaan.

Pengaruh keadilan proses seleksi terhadap daya tarik organisasi memiliki path coefficient sebesar 0,209 dengan nilai $t$-statistics sebesar 2,223. Nilai t-statistics tersebut lebih besar dari nilai t-tabel yaitu 1,96 yang dapat diinterpretasikan adanya pengaruh positif dan signifikan antara variabel keadilan proses seleksi dan daya tarik organisasi. Path coefficient menunjukkan bahwa keadilan proses seleksi memberikan pengaruh positif 
terhadap daya tarik organisasi. Hal ini berarti bahwa semakin tinggi keadilan proses seleksi, maka semakin tinggi pula tingkat daya tarik organisasi.

Pengaruh negosiasi gaji terhadap daya tarik organisasi memiliki path coefficient sebesar 0,270 dengan nilai $t$-statistics sebesar 2,501. Nilai $t$ statistics tersebut lebih besar dari nilai t-tabel yaitu 1,96 yang dapat diinterpretasikan adanya pengaruh positif dan signifikan antara variabel negosiasi gaji dan daya tarik organisasi. Path coefficient menunjukkan bahwa negosiasi gaji memberikan pengaruh positif terhadap daya tarik organisasi. Hal ini berarti bahwa semakin tinggi negosiasi gaji, maka semakin tinggi pula tingkat daya tarik organisasi.

Pengaruh reputasi perusahaan terhadap daya tarik organisasi memiliki path coefficient sebesar 0,499 dengan nilai $t$-statistics sebesar 3,789. Nilai $t$ statistics tersebut lebih besar dari nilai t-tabel yaitu 1,96 yang dapat diinterpretasikan adanya pengaruh positif dan signifikan antara variabel reputasi perusahaan dan daya tarik organisasi. Path coefficient menunjukkan bahwa reputasi perusahaan memberikan pengaruh positif terhadap daya tarik organisasi. Hal ini berarti bahwa semakin tinggi reputasi perusahaan, maka semakin tinggi pula tingkat daya tarik organisasi. Penambahan variabel reputasi perusahaan sebagai pemediasi memberikan pengaruh berbeda terhadap hubungan langsung keadilan proses seleksi terhadap daya tarik organisasi.

\section{SIMPULAN DAN SARAN}


Berdasarkan analisis dan pembahasan yang telah dikemukakan, maka sebagai kesimpulan dan hasil penelitian yaitu keadilan proses seleksi berpengaruh positif dan signifikan terhadap reputasi perusahaan, artinya semakin baik keadilan proses seleksi, maka semakin tinggi pula reputasi yang dimiliki perusahaan tersebut. Negosiasi gaji berpengaruh positif dan signifikan terhadap reputasi perusahaan, artinya semakin baik negosiasi gaji perusahaan, maka semakin tinggi pula reputasi yang dimiliki perusahaan tersebut. Keadilan proses seleksi berpengaruh positif dan signifikan terhadap daya tarik organisasi, artinya semakin baik keadilan proses seleksi, maka semakin tinggi pula daya tarik organisasi tersebut. Negosiasi gaji berpengaruh positif dan signifikan terhadap daya tarik organisasi, artinya semakin baik negosiasi gaji yang diterapkan perusahaan, maka semakin tinggi pula daya tarik organisasi tersebut. Reputasi perusahaan berpengaruh positif dan signifikan terhadap daya tarik organisasi, artinya semakin baik reputasi yang dimiliki perusahaan, maka semakin tinggi pula daya tarik organisasi tersebut. Reputasi perusahaan sebagai variabel pemediasi berpengaruh positif dan signifikan terhadap hubungan keadilan proses seleksi dengan daya tarik organisasi, artinya reputasi perusahaan memiliki peran penting dalam memediasi keadilan proses seleksi terhadap daya tarik organisasi. Reputasi perusahaan sebagai variabel pemediasi berpengaruh positif dan signifikan terhadap hubungan negosiasi gaji dengan daya tarik organisasi, artinya reputasi perusahaan memiliki peran penting dalam memediasi negosiasi gaji terhadap daya tarik organisasi. 


\section{REFERENSI}

Adkins, C., Russell, C., and Werbel, J. 1994. Judgments of Fit in the Selection Process: The Role of Work Value Congruence. Personnel Psychology, 47, 605-623.

Anderson, N., Ahmed, S., Costa, A. 2012. Applicant Reactions in Saudi Arabia: Organizational Attractiveness and Core-self Evaluation. International Journal of Selection and Assessment, Vol. 20, No. 2, pp. 197-208.

Arvey, R., and Renz, G. 1992. Fairness in the Selection of Employees. Journal of Business Ethics, 11. 331-340.

Barber, A., and Bretz, R. 2000. Compensation, Attraction, and Retention. Journal of Compensation, 44, 32-60.

Bertolino, M., and Steiner, D. 2007. Fairness Reactions to Selection Methods: An Italian Study. International Journal of Selection and Assessment, Vol. 15, No. 2, pp: 197-205.

Cable, D., and Turban, D. 2003. The Value of Organizational Reputation in the Recruitment Context: A Brand-Equity Perspective. Journal of Applied Social Psychology, Vol. 33, No. 11, pp. 2244-2266.

Fomburn, S. 1996. Reputation Building and Corporate Strategy. Academy of Management Journal, Vol. 33, No. 2, pp. 233-258.

Froese, F., Anne, V., and Garrett, T. 2010. Organizational Attractiveness of Foreign-Based Companies: A Country of Origin Perspective. International Journal of Selection and Assessment, Vol. 18, No. 3, pp. 271-281.

Gatewood, R., Gowan, M., and Lautenschlager, G. 1993. Corporate Image, Recruitment Image, and Initial Job Choice Decisions. Academy of Management Journal, Vol. 36, No. 2, pp. 414-427.

Gerhart, B., and Rynes, S. 1991. Determinants and Consequences of Salary Negotiations by Male and Female MBA Graduates. Journal of Applied Psychology, Vol. 76, No. 2, pp. 256-262.

Gilliland, S. 1993. The Perceived Farness of Selection Systems: An Organizational Justice Perspective. Academy of Management Review, 18, 694-734.

Hoye, G., and Lievens. 2009. Tapping the Grapevine: A Closer Look at Word-ofMouth as a Recruitment Source. Journal of Applied Psychology, Vol. 94, No. 2, pp. 341-352. 
Keller, K. 1993. Conceptualizing, Measuring, and Managing Customer-Based Brand Equity. Journal of Marketing, 57, 1-22.

Leibbrandt, A., and List, J. 2012. Do Women Avoid Salary Negotiations? Evidence From A Large Scale Natural Field Experiment. National Bureau of Economic Research, 93, 1-26.

Lievens, F., Decaesteker, C., Coetsier, P., and Geirnaert, J. 2001. Organizational Attractiveness for Prospective Applicants: A Person-Organisation Fit Perspective. Applied Psychology: An International Review, Vol. 50, No. 1, pp. 30-51.

Lis, B. 2012. The Relevance of Corporate Social Responsibility for a Susrainable Huna Resource Management: An Analysis of Organizational Attractiveness as a Determinant in Employees Selection of A (Potential) Employer. Management Review, Vol. 23, No. 3, pp. 279-295.

Marin, L., and Ruiz, S. 2007. "I Need You Too!" Corporate Identity Attractiveness for Consumers and The Role of Social Responsibility. Journal of Bussiness Ethics, 71, 245-260.

Porter, C., Conlon, D., and Barber, A. 1999. The Dynamics of Salary Negotiations: Effects on Applicants Justice Perceptions and Recruitment Decisions. The International Journal of Conflict Management, Vol. 15, No. 3, pp. 273-303.

Schinkel, S., Vianen, A., and Dierendonck, D. 2013. Selection Fairness and Outcomes: A Filed Study of Interactive Effects on Applicant Reactions. International Journal of Selection and Assessment, Vol. 21, No. 1, pp. 2231.

Schreurs, B., Druart, C., Proost, K., and Witte, K. 2009. Symbolic Attributes and Organizational Attractiveness: The Moderating Effects of Applicant Personality. International Journal of Selection and Assessment, Vol. 17, No. 1, pp. 35-46.

Sulalman, A. 2017. Awas, Indonesia akan Kekurangan Tenaga Kerja Profesional Kelas Menengah.(online),(https://www.senayanpost.com/awas-indonesiaakan-kekurangan-tenaga-kerja-profesional-kelas-menengah/)

Tsai, W., and Irene, Y. 2010. Does Image Matter to Different Job Applicants? The Influences of Corporate Image and Applicant Individual Differences on Organizational Attractiveness. International Journal of Selections and Assessment, Vol. 18, No. 1, pp. 48-63.

Turban, D., and Keon, T. 1993. Organization Attractiveness an Interactionist Perspective. Journal of Applied Psychology, Vol. 78, No. 2, pp. 184-193. 
Turban, D., Lau, C., and Steven, S. 2001. Organizational Attractiveness of Firms in the People's Republic of China: A Person-Organizational Fit Perspective. Journal of Applied Psychology, Vol. 86, No. 2, pp. 194-206.

Wartick, S. 2002. Measuring Corporate Reputation: Definition and Data. Business and Society, Vol 41, No. 4, pp. 371-392.

Williamson, I., James, E., Lepak, D., and Sarma, A. 2010. Firm Reputation, Recruitment Website, and Attracting Applicants. Human Resource Management, Vol 49, No. 4, pp. 669-687.

Wiyono, G. 2011. Merancang Penelitian Bisnis dengan Alat Analisis SPSS 17.0 dan Smart PLS 2.0. Yogyakarta: STIM YKPN. 